\title{
Ruler, Protector and Healer: The Clan Gods Sulia, Patkhanda and Sikerpat of the Kondh Tribe
}

\author{
Cornelia Mallebrein
}

\section{INTRODUCTION}

This paper focuses on three important clan deities of the Kondh, Patkhanda, Sulia and Sikerpat, who are widely worshipped in Bolangir District. ${ }^{1}$ Each deity is affiliated with one subgroup (chak) of the Kondh tribe. ${ }^{2}$ Their main area of worship is a small region in Bolangir District enclosed by the hills of Kandhamal District and Kalahandi. The powerful river Tel and its tributaries ${ }^{3}$ flow through this region, turning into raging torrents during the monsoon period, thus making interaction and communication between different areas difficult. The wellknown villages of this area are the former zamindaris of Athgaon and Jarasingha, Tushara and Guna in the Guduvella region. Within this area, the Kondhs are the dominant tribal group. ${ }^{4}$ The main centres of worship of these three clan gods are Jarasingha ${ }^{5}$, which has a modern temple to Patkhanda and Khairaguda ${ }^{6}$ with its small traditional shrine ( $g u d i)$ to Sulia and Ghuna ${ }^{7}$, the main centre of Sikerpat worship. Each god is linked to a specific Kondh sub-group, such as Patkhanda with the Mutkia Kondh and Sulia with the Maunsia Kondh, while Sikerpat is the main deity god of the Khandgia Kondh. ${ }^{8}$ All these Kondh groups are related as either "brothers" (bhai) or "friends" (bandhu). ${ }^{9}$

What makes these deities so fascinating is their history of origin, as told in various legends, and their gradual shift away from their being worshipped in the dense forests of the Kondhmal Hills to the plains. Analysis of their legends shows that they mirror the former migration of various Kondh groups from the jungle to this fertile region, which at that time was ruled by powerful Chauhan kings and their zamindari rulers. The kings summoned the Kondhs into their area and gave them the right to clear the forest and start rice cultivation. ${ }^{10}$ In return, the Kondh assisted the Raja as soldiers in times of war. Kondh warriors were famous as fiereless fighters ${ }^{11}$ and were therefore in high demand with the local Rajas who were settled at the feet of the
Kondhmal Hills and were constantly fighting their neighbours. On their way from the hills to the plains, the various Kondh groups were accompanied by their clan gods, so that fascinating traditional festivals and rituals entered this part of Bolangir District. These festivals have maintained their tribal character and vibrant, unrestricted style of performance until today. It is the medium, the "living god on earth", who plays the dominant role in this divine play.

In course of time old tribal ideas and concepts from time immemorial incorporated certain traditional Hindu religious concepts, but deities like Patkhanda, Sulia and Sikerpat are still rooted in their tribal origins. In the rapidly changing conditions of the present day, they are now on the verge of becoming incorporated and assimilated into "codified Hinduism". ${ }^{12}$ What makes these clan deities so important is the fact that they have still not lost their identity as autochthonous tribal deities. Thus their jungle origins are reflected by their iconography. It is not the iconic murti that is at the centre of worship, but their aniconic representations, such as a sword (Patkhanda), an axe (Sulia), a simple water pot or a bamboo stick (Sikerpat).

But of central importance within the context of worship are the mediums, the deities' visible representatives on earth. Entering an altered state of consciousness, they embody the divine and become their mouthpiece. This medium may be the deity's priest or deheria, or a special person selected by the deity itself, the deheri. ${ }^{13}$ During festivals they represent the deity on earth, in that state transferring divine energy on to the participants. Holding objects charged with the deities' power in their hands, they touch the shoulders of the devotees who are seeking help, then run their hands all over the body. In this way, their bodes are charged and empowered with both healing qualities and protective divine power. As a thanksgiving, the devotees offer a great number of animals to the deities, often hundreds during a festival. ${ }^{14}$ For them, the gods need the 
life-force of blood to replenish and renew their energy; only then they can take responsibility for the world of the living, bestow fertility on men and animals, and solve the daily problems of their devotees who are seeking their help, be it health problems, a court case or unemployment. The deities Sulia, Sikerpat and Patkhanda take equal care of all their followers, whether tribal or Hindu, as gods do not differentiate-in the god's eye, everyone is the same. For the participants, the huge quantity of animal sacrifices offered to the respective gods during festivals is a clear sign of their immense power, which has its roots in their tribal origins. This is still reflected in their rituals. As a tribal deity, they demand a form of worship that recalls the time of their former jungle worship, when the traditional dress of the priest was made of leaves only. ${ }^{15}$ Therefore Sulia and Sikerpat only accept a priest wearing a loincloth made out of leaves ${ }^{16}$ at puja, and not the dress code of modern civilisation. For Sikerpat, young people in trousers, shirts or shoes, or even carrying an umbrella made out of cloth, should not participate in the rituals at the sacred site. ${ }^{17}$

But it is especially the curing of infertility that brings fame to these clan gods. For a childless women, it is the male virile power that is transferred to her by the deheri during trance. ${ }^{18}$ According to the devotees, the success rate of healing is more than $80 \%$; no goddess can show this result.

\section{MAHASINGHI: THE POWERFUL CENTRE AND PLACE OF ORIGIN}

Sulia, Sikerpat and Patkhanda are said to originate from Mahasinghi, a small place near Baliguda subdivision in Kandhamal District. People refer to this place with respect and at the same time shudder, because Mahasinghi has a reputation for its former extensive performance of human sacrifices. Although this custom goes back into the past, there is still a rumour that the practice carries on secretly. Mahasinghi is one of the most powerful places in the BaligudaPhulbani region. ${ }^{19}$ The various Kondh clans and their strong and dangerous gods do originate in this area, but although they are said to come from Mahasinghi, the legends about their moving to the Bolangir plains are quite different.

The clan gods Sikerpat and Sulia are linked with a story that is quite common in the tribal hilly regions of Orissa and told in connection with many other gods. Wherever this story is told, there is a hint that the deity originated in the tribal sphere but left her exclusive tribal worship to become accessible to a new clientele of devotees from the Hindu fold. In this story, the deity throws her priest's forgotten ritual water pot from the place of worship high in the inaccessible mountains down to the plains, with the command that her devotees should worship her at the spot where the water pot comes to a rest. ${ }^{20}$ This indicates that the deity has left the forest (vana) to settle in a cultivated area (ksetra). ${ }^{21}$ The coming down of hill gods, often spirits like clan gods, is well known all over India. $^{22}$

Concerning the legend of the first human sacrifice at Mahasinghi one informant narrates the legend that Kandenbudhi, a Kondh women, ordered her twelve sons to kill her and cut her body into many pieces, then to bury them to make the earth solid, as it was shaking at the time. Thanks to Kandenbudhi's self-sacrifice and her blood and flesh, life on earth developed. ${ }^{23}$ It is said that, at the site of the Kandenbudhi's sacrifice, the twelve sons erected twelve wooden stumps in her memory, this being the reason why the village people in this region erect a wooden pole in the village centre for the goddess and regularly offer her animal sacrifices, rice and liquor. ${ }^{24}$ Then the villagers ask her to ensure the fertility of the fields and the protection of the whole village together with its inhabitants, both men and animals. They believe that the blood and meat of the sacrificial animal nourishes and strengthens her, thus reviving her life-giving powers.

\section{SIKERPAT, THE CLAN GOD OF THE KHANDGIA KONDH}

The legend tells how the Khandgia Kondh originated from Luching Padar, a forest region near Mahasinghi. The founders of the Khandgia clan were staying in this jungle. The names of the six brothers were Sen, Men, Klis, Kanda, Kaman and Daman. Every day they went to the forest together with their brother-in-law, a Cherkia Kondh. One day they suddenly saw a strange and unknown animal like a cow with huge ears. ${ }^{25}$ This forest animal used one of its ears to cover the floor and the other like a blanket to cover its body. This strange animal was Sikerpat. Seeing it, the five elder brothers went into the 
forest to wake up Sikerpat, but without success. Then the youngest went into the forest to try his luck, where he made a bamboo flute and started playing. When Sikerpat heard the sweet tones, he opened his eyes and spoke: "You have disturbed my sleep by waking me up; from now on you will have to worship me". Hearing this, the brother said: "If you give us good crops and help in all parts of our life, then we shall worship you". Sikerpat agreed, and they started worshipping him on the high Budha Dongar, afterwards called Siker Dongar. But one day the deheria (the priest) left his ritual water pot at the sacrificial spot. Again he climbed up high into the mountains. There, hiding behind a tree, he saw Sikerpat surrounded by many gods and goddesses, his friends, sharing the priests' offerings. Again and again the gods divided up the shares, but each time one share was left. Becoming irritated by the extra share, they suspected the presence of an unwanted onlooker and then caught the priest hiding. Sikerpat became furious at the presence of this uninvited guest and questioned the priest about why he was there. The latter promised that it would never happen again and in a rage hurled his water pot down the hill, the pot hitting the root of a tree. Every year until today the Kondh perform a largescale jatra $^{26}$ at this very spot near the village Ghuna in honour of Sikerpat. Two bamboo poles represent Sikerpat and his wife Pahagiren. ${ }^{27}$ The devotees flock to the sacred spot from more than forty villages to participate and offer a huge number of buffalo and goat sacrifices. ${ }^{28}$

\section{SULIA, THE CLAN GOD OF THE MAUNSIA KONDH}

The clan god Sulia of the Maunsia Kondh also originates from Mahasinghi. According to a legend he once accompanied an ancestor of the present Kuar ${ }^{29}$ Kondh family of Khairaguda, who belongs to the Maunsia chak. Together they went to Puri, up to the great steps of the Jagannath temple. From there Sulia brought back three puti full of rice as prasad from Jagannath. At that time the Kuar ancestor was an army officer or senapati. He moved with these followers over to the left bank of the river Tel near Tusra, and Sulia, his clan god, accompanied him. Sulia looked around him and decided to settle on a huge mountain, Bada Dongar, which later became the Sulia Dongar. The ancestors of the Kuar Kondh worshipped Sulia, whose symbol was an axe (tangi) with a handle made out of bamboo, at this spot. On his way up to the hill, Sulia stopped for a rest in a small village under a Khaira tree, where he erected a hut (gudi). This small village was later named "Khairaguda" after this hut placed under a Khaira tree. The devotees say that the former hut was later changed into the present-day Sulia shrine of Khairaguda. One day the priest left his ritual pot ( $g h a d u)$ at the sacrificial spot on the Sulia mountain. When he returned, he saw the gods sharing the animal sacrifices, but always one share was left. Angry because of the priest's presence, the clan god Sulia threw the pot down the hill towards the plain. At the spot where the pot fell, the yearly Sulia puja, a large festival with thousands of participants, is held. The close connection of the Maunsia Kondh with Mahasingi is expressed by the fact that the priest of Sulia is not a member of the Maunsia Kondh, but of the Sehelia Kondh from Mahasinghi, who are considered very traditional and orthodox.

Until today the priests of all these clan deities, not only of Sulia's, must follow certain purity rules. As a consequence, they are not allowed to eat in the house of a non-family member, sit on a bed, take part in a funeral, wear shoes or travel by bus. According to Sulia's present priest, the headman (kuar) of the Khandgia Kondh first performed the puja, ${ }^{30}$ then received the title and role of an Umra, thus ceasing to be in a position to observe the strict purity rules. ${ }^{31}$ Sulia became very angry and, assuming the form of a tiger, killed all his children. When there was only one son left, he asked Sulia for advice and was told that he would only accept a Sehelia Kondh as priest. $^{32}$ The Kuar called a Sehelia Kondh family to take over the worship, for which they received free land for cultivation. At that time the Kuar held the position of an Umra for the three villages of Hilimal, ${ }^{33}$ Telpani and Khairaguda, which were given to him by the king of Jarasingha.

\section{PATKHANDA, THE CLAN DEITY OF THE MUTKIA KONDH}

The legend of Patkhanda also mirrors the gradual movement of a Kondh sub-group, the Mutkia Kondh, from the region of Mahasinghi to Jarasingha. ${ }^{34}$ According to one story, Patkhanda stayed in the house of a Mutkia Kondh in the form of a powerful and magical 
paniki, a vegetable chopper which automatically cuts anything placed on it. Once the Kondh took a loan from a Brahman. As he could not pay it back, the Brahman stole the magic paniki. Immediately the deity showed her presence and anger by breaking it into three pieces. He tried everything to keep the deity with him, but she disappeared, vehemently refusing to stay with the Brahman. She decided to leave her place of origin together with her brother Birpani and her adopted brother Jenabudha. They went northwest from Mahasinghi, via Kotgad, Baliguda and Bhuanpada, and finally to Jarasingha, ${ }^{35}$ where Patkhanda first asked the local hill god, Budha Dangar, for permission to stay. ${ }^{36}$ But he advised her to ask Pataneshvari and Samleshvari, the family deities of the Patnagarh Chauhan kings, to grant this favour. Patkhanda assisted Vatsarajadeva, the king of Patnagarh, in his war against the king of Bastar. Thanks to Patkhanda's magical insight, he won the war. She discovered that the king of Patnagarh had lost all his wars because Bastaren, the family deity of the king of Bastar, sold poisoned food to the soldiers. They seized her, together with the brothers of Patkhanda, Jenabudha and Birpani. The Chauhan king won the war, and in return for her decisive help in it, Patkhanda obtained the area of Jarasingha from the Chauhan king as her new region to rule.

In the case of Patkhanda, we do not have the story of a pot being thrown down to the plains, as she was never worshipped on a hill, her sacred spot being a mahua tree in a small forest grove near Jarasingha, from where parts of the paniki appear miraculously every year at the beginning of the Patkhanda jatra. Patkhanda is called "Rajadevata", meaning that she has left the purely tribal fold which characterizes Sulia and Sikerpat to enter the royal court of a Hindu ruler and thus the sphere of brahmanical worship. ${ }^{37}$ Patkhanda was adopted by the royal zamindar family of Jarasingha as their istadevata. Since the end of the nineteenth century was marked by a wave of new royal town construction, the zamindari family of the small village of Jarasingha followed the regional kings and started to construct their own centre of power, with a fine palace, a modern temple for Patkhanda, a large Jagannath temple and a shrine for the village goddess Bastaren. ${ }^{38}$ Although the Zamindari Raja employed Brahmans to look after the rituals held in his palace and at the Jagannath temple, the priest of Patkhanda is still a member of the Kondh tribe today. ${ }^{39}$ The yearly festival for Patkhanda was integrated into the Dashahara festival. ${ }^{40}$ During the five-day festival, the Kondh priest or thanapati embodies the deity.

Whereas Sulia and Sikerpat are considered male gods, the clan deity Patkhanda is said to unite in herself male as well as female qualities. Her male qualities are needed to heal women from infertility. It should be noted that the way the healing rituals are performed is similar for all the clan deities. In Jarasingha, the healing of infertility takes place in the late afternoon and evening of the main day, after the priest has emerged from the forest grove in a state of trance. The dancing deity is guided by two helpers. In his hands the priest holds three small metal sticks the size of a finger which are said to contain the divine power of Patkhanda. As already mentioned, the devotees say that these metal parts miraculously appear every year at this time at the foot of a mahua tree growing at a spot called deyjhar. ${ }^{41}$ The priest as well as the medium of Birpani in trance, decorated with flower garlands in their role as "gods on earth", recall the movement of the Mutkia Kondh from the dense jungle to the open plains, from the vana to the kshetra. That time Patkhanda is considered as a male deity, an old clan deity of the Mutkia Kondh. When Patkhanda entered the sphere of Hinduism as an istadevata of the royal family of Jarasingha she changed into a female deity, and under the influence of the Brahmin priests of the royal court she was linked with Durga and her festival was incorporated into the Dussera-festival, the major festival celebrated by the local Rajas. Traditionally the festivals for the clan deities of the Kondh tribes where performed in the month of pausa (see Sulia, Sikerpat). The dance of Patkhanda and Birpani is an expression of joy. A group of Dhombo musicians form the first reception committee, a short distance away from the entrance to the forest, at the baragharia spot. One musician plays a large double-headed drum or dhol. According to the priest, the drum conceals Patkhanda's wife, Hinjalrani, a Harijan girl. Listening and dancing to the music, Patkhanda suddenly jumps on to the drum with both legs. For the onlookers this is a moment of the greatest fertility, since it represents the sexual union of the god - at that stage male - with his wife. The procession proceeds towards another sacred spot, jairasal, to perform the ritual healing. 
Many couples have already been sitting on the special platform erected there since the early morning. Then Patkhanda asks them one by one to lay down on the ground and starts dancing over their body; he asks them to stand up and repeatedly presses the metal parts of his hands on to the women's wombs. According to the priest of Patkhanda, this cleans the women's bodies for their husband's semen to pass into them. Patkhanda is famous for a high rate of success in healing.

The three finger-length small sticks wrapped in red cloth are the focus of the Patkhanda festival. The priest can only use their divine energy for healing purposes for a very short time, not only in cases of disease and infertility, but also possession by an evil sprit. On the last day of the festival, Patkhanda goes back to the forest from where she came, and the priest leaves the metal parts at the root of the mahua tree, from which they miraculously disappear.

\section{A CLOSER LOOK AT SULIA AND HIS FESTIVAL}

Sulia from Khairaguda is also famous for his healing power. Men and women gather in front of the small Sulia shrine the night before the great Sulia jatra begins at the jatra padia. ${ }^{42}$ In this case Sulia's priest is not linked with healing rituals, which are performed instead by a deheri, who represents Sulia on earth. According to the priest, only Sulia has the power to heal people of infertility. ${ }^{43} \mathrm{He}$ is assisted by three other deheri, who do the other types of healing. ${ }^{44}$ Sulia's divine power is hidden in a special metal chain (sikla) with pendants, which the deheri hold in each hand during trance. The deheri repeatedly touch the shoulder and bodies of the devotees with the metal chains. The devotees have come to communicate with Sulia and the hill gods Pathargada and Pahajuren, who are present at that time and are represented by their deheri. ${ }^{45}$ During their dialogue with the divine, the devotee describes his problems, then the deheri promises that all their hopes will be fulfilled. Belief in the power of the gods remains unbroken today, including for young people, who attend the ritual and festival in great numbers.

According to the deheri, it is the deity who selects her representative on earth, often from a family whose members traditionally act as deheri; the deity tries to continue the succession, choosing a grandson as her medium after the grandfather has stopped officiating. Often the invocation takes place all of a sudden, without prior warning, on a normal day. The deity forces the young boy to become her deheri or impersonator. For the latter this means great responsibility, which they try to avoid, though they are never able to resist the god's demands. Being a deheri requires great physical strength.

On the first day of the Sulia festival, ${ }^{46}$ the deheri and deheria start their fast, then perform the ritual in the Sulia shrine in Khairaguda at night. After finishing, the deheri enter the village, where a huge crowd of villagers surrounds them, eager to have an opportunity for a brief communication with the divine. During their journey, the deheri, being gods on earth, must speak in a specific god-like way, sometimes soft, then suddenly harsh and wild. Their behaviour changes within a second, at one time delighting themselves in joyful dancing, then suddenly beating themselves or even the god's devotees with their iron chains (sikla) in a rage. ${ }^{47}$ This ambivalent behaviour is a characteristic mark of divine beings generally, not only tribal gods. For the Sulia priest (pat-deheria) and the deheri the night is short: they must leave Sulia's shrine (kothigarh) in the early morning at four o'clock to fetch Sulia's old axe (pat-tangi). Since this axe should not touch the earth, it is hung on a wooden pole coloured red in Sulia's shrine. The main rituals of the day take place at a spot about a kilometre outside Khairaguda in an open cement enclosure constructed in 1971. This is said to be the spot (jatra padia) where the water pot of the priest formerly fell down. Nobody is allowed to see the axe on their way from the shrine to the ritual spot, and a trumpet is sounded to warn people to hide. In the morning, at around nine o'clock, ${ }^{48}$ all the preparations having finished, the ritual begins within the enclosure. ${ }^{49}$ The focus of worship are three small bamboo sticks filled with raw rice grains. For the devotees, Sulia's power and its presence during the festival receive visible proof when the rice grains in the bamboo stick are miraculous transformed into cooked rice without any water or heat. Once this miracle has happened, the deheri start entering trance, their bodies tremble, their long hair whirls through the air. At the same time the priest (deheria), now dressed in a loincloth made out of siali leaves, throws rice which has been cooked separately into the air, thus offering it to all the gods and 


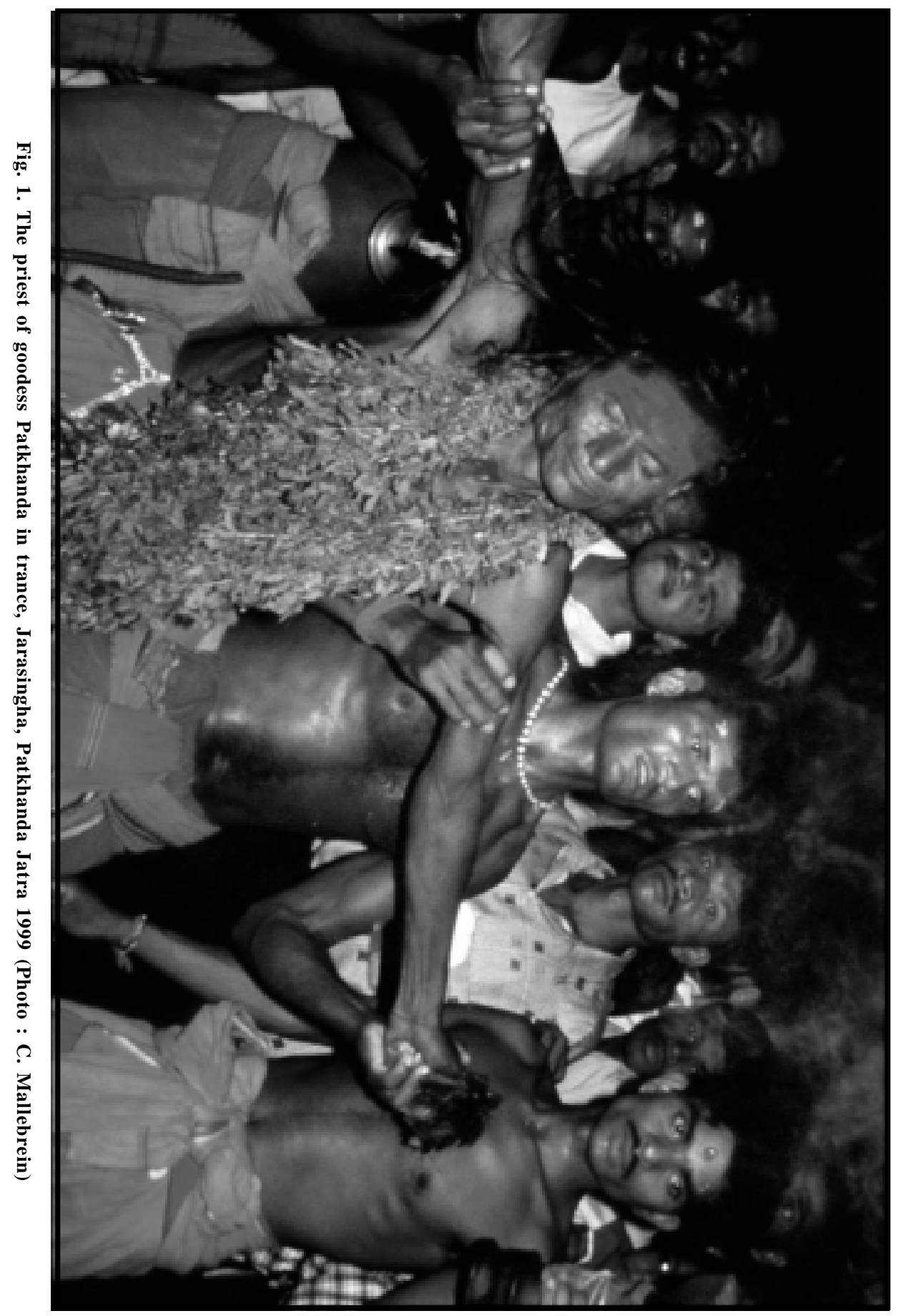


goddesses, who are said to have come to participate; the devotees speak of more than $110 .^{50}$ Then the deheri of Sulia, Pahagiren ${ }^{51}$ and Pathargad $^{52}$ leave the inner enclosure where the miracle took place to attend the endless animal sacrifices $^{53}$ that are performed at various spots within and around the cement enclosure. People demand the presence of the deheri during the sacrifice until evening. Upon seeing their offerings they dance in a joyful mood, but also beat themselves to show their discontent with devotees' offerings, from time to time suddenly lifting up the body of a goat that has just been beheaded to drink the blood gushing from the animal's neck in a greedy, thirsty mood. In their role as gods on earth, the deheri must attend and enjoy the sacrifices, but this role is very hard and exhausting. Several times during the day they ask to rest, upon which the deity leaves their body, and they seek shelter in a hidden space within the cement enclosure. But already after a short time the devotees are demanding their presence again, so that the gods should see and partake in their offerings. Finally, at sunset, after the sacrifice of numerous buffaloes, the festival comes to an end. The festival committee now starts counting the sacrificed animals. For the devotees this is a crucial moment, for the number of animals indicates the number of wishes Sulia fulfilled last year, a visible and countable sign of his power. ${ }^{54}$

Today public opinion about animal sacrifice is divided. ${ }^{55}$ Opposition to the performance of such sacrifices is spreading, and people are beginning to question the point of killing so many animals. During the Sulia festival in 2003, followers of the Gayatri movement started a campaign against it. They were allowed to erect a tent and loudspeakers at a good distance from the centre of worship and animal sacrifices. A group of mainly young people gathered for a joint protest: "Plant trees, don't kill animals. Stop sacrificing animals."

For these activists animal sacrifice and the performance of the deheri is nothing other than a huge business benefiting the organizing committee and certain participants like the musicians, priests, deheri and deheria, as well as the police who is asked to look after law and order. Parts of the animals that are offered are sold by the festival committee to the public as prasad. But the loud protest of the Gayatri activists was hardly heard by the thousands of mainly male tribal visitors hurriedly passing their tent in their eagerness to enjoy the numerous stalls and food stores set up for the fair, though the main attraction was to see the animals being sacrificed. Some local TV stations had sent their reporters to document the 'cruel' killing of animals and the deheri in trance smearing blood all over their bodies. For television, the Gayatri activists provided an interesting contrast to the ritual. Thus the Gayatri protest group were given numerous opportunities to state their objections to the TV cameras that broadcast programmes on the ritual throughout Orissa.

\section{TRIBAL DEITIES IN THE $21^{\text {sT }}$ CENTURY}

Along with the trend towards ceasing animal sacrifices, the number of devotees who express a strong belief that these important clan gods are in reality vegetarian deities, that they do not drink blood, is growing. In the eyes of these devotees, as well as Sulia's tribal priests (deheri), he only takes rice as an offering since Sulia in his real form is an avatar of Shiva. ${ }^{56}$ The name Sulia comes from "trisul". ${ }^{57}$ This shows that the process of incorporating tribal deities into Hinduism has lost none of its dynamics. For these devotees, the large number of animal sacrifices are only given to the parshvadevata, the dangerous bloodthirsty deities who accompany Sulia. This idea is also expressed by the priest of Patkhanda, who denies that Sulia takes animal sacrifice. According to him, the medium drinks the blood on behalf of protective forces such as Chandi, Chamunda and her furious army ${ }^{58}$ This trend towards raising tribal deities up to the status of a superior, vegetarian god corresponds to recent attempts in Orissa to abolish animal sacrifices, in which it marks the first step. In recent years especially, buffalo sacrifice has ceased at many temples in Orissa, but the sacrifice of goats is now also being vigorously discussed. One reason for this is the present wave of impressive new temple constructions, which is taking place all over Orissa.

After the local temple and traditional mud shrines (gudi) have been replaced by splendid colourful cement temples, animal sacrifice must leave the inner circle for the periphery, the intention being to have it stopped permanently. The new temple, with its white marble flooring, is not suitable to have blood pouring all over it. 


\section{CONCLUSION}

Orissa is in a state of flux. Many of the traditional festivals and rituals will change, the wild and unrestrained character of the tribal deities will be tamed, and their thirst for blood and hunger for meat will be satisfied with coconut milk, pumpkins and vegetarian offerings. As a peaceful vegetarian deity, the memory of their origin from the dense inaccessible and dangerous jungle is being lost. They have left the jungles of this world and taken their abode in a remote Puranic heaven, from where they come into this world as an avatar of Shiva or Durga. The former tribal priest is then replaced by a Hindu priest, often a Brahman; the deity ceases to possess a medium (dehuri, kalisi) and thus ceases to appear as a visible, immediately amenable and responsive deity. Her cults now pacified, the formerly 'uncontrolled, wild and dangerous' deity has been brought under control.

KEYWORDS Tribal deities; local festival; Kondh deities; local kings and rulers

ABSTRACT One characteristic feature of the religious map of Orissa is the multitude of deities who are of tribal origin. In the rapidly changing conditions of the present day, they are now on the verge of becoming incorporated and assimilated into 'codified Hinduism' and thus identified with one of the great gods like Shiva or Durga. The legends of their history of origin reflect the movement of the tribal groups that are linked with the deities from the jungle to the plains. The Sulia, Sikerpat and Patkhanda clan deities of various Kondh groups are among those deities that are on the verge of this change.

\section{NOTES}

1 This paper is based on several field trips in this area between the years 1999-2003. The author expresses her thanks to the German Research Council (DFG) who made this research on the Hinduised tribal deities of Orissa possible. I also acknowledge with gratitude the support I received from Mrs Biwasini Rath (M.A.) and Mr Devdas Mohanty in 19992000. My thanks also go to my Research Assistant Mr Dillip Sethi (M.A.) for his helpful support and suggestions regarding the work of documentation since the year 2000. Fieldwork on Patkhanda, Sulia and Sikerpat received generous help from Shri Parasuram Singh Deo, Zamindar-Raja of Jarasingha, the priest Rajkumar Thanapathi of Jarasingha, the Gontia family of Niroj and Pramod Tripathy at Khairaguda, Biranchi Kuar of Hilimal, and the dehuria and dehuri from nearby villages. I further thank Prof. Dr. H. von Stietencron for his valuable comments on this paper.

2 The Kondh of this area speak Oriya, having given up their traditional Kui language for more than three generations. They do not maintain close relations with the Kui-speaking Kondh of the Phulbani-Mahasinghi area.

3 Tributaries of the Tel river are the Raul and Kharag (Guduvella) and Sonegarh (Tushara, Jarasingha).

4 Among the different tribal groups, the Gonds are also very prominent. Their gods are worshipped widely in this area, such as Budha Raja (Athgaon). There is controversy between the Kondh and Gond regarding who came first to the area. The Kondh claim this right for themselves by telling the story about the Chauhan king asking the Gond and Kondh for proof of their settlement. As proof the Kondh referred to their traditional way of cooking - they place their cooking pot on three stones (itla) which marks each settlement. As the Gond use perishable mud to construct a cooker, they could not prove early settlement in this region, so the Kondh won the contest.

$5 \quad \mathrm{~N} 20^{\circ} 31.509$, E $083^{\circ} 27.978$

$6 \mathrm{~N} 20^{\circ} 34.319, \mathrm{E} 083^{\circ} 34.635$

$7 \quad \mathrm{~N} 20^{\circ} 25.221$, E $083^{\circ} 34.651$

8 The paper focuses only on the three clan gods of Patkhanda, Sulia and Sikerpat, the most important clan deities in this area. The two other Kondh groups in this area and their clan deities are: Kuturkia Kondh: clan god Bakri Ulia and Bhim; Turkia Kondh: clan gods Bonkhai/Bamkhai, Gaikhai, Delaguru Pinjepat, Bad Kharsel, and San Kharsel.

9 On this terminology and present changes in kinship, cf. B.K.Behera, 1996: 113-127

10 According to Berkemer 1993: 7, "the cutting of the jungle, foundation of temples, villages and towns, providing land for cultivation...and patronizing local cults were major tasks for the kings. In this way, the 'frontier' Hindu civilization moved into the hilly tracts".

11 For a depiction of "Khonds dressed for Battle" by W. Macpherson, published in 1865 , see Hacker 1999, Fig. 3.

12 In her study of the Hinduization of Tribal deities in Orissa, Eschmann 1978: 82 writes: "Hinduization acts in between codified Hinduism and tribal religions. It is therefore bound to combine and transform these main functional characteristics of both types of religion. Within this process several main stages can be distinguished".

13 The priest of Sulia is called deheria, this expression changes within Orissa. At Ghagaon the priest of goddess Tarini is called dehuri.

14 During the Sulia festival in 2003, people estimated that around 80 buffaloes, 400 goats and more than 800 chickens were offered.

15 The Juang are well known for their leaf dress, which is depicted in early British colonial writings; cf. E.T. Dalton 1872, Plate XXXIII.

16 This is made out of fresh green Siali leaves. Formerly the priest did the ritual naked, at which time no one else was allowed to attend.

17 Women are still not allowed to participate at the ritual site today.

18 The women also drink the panchamrit from the temple in hopes of becoming pregnant.

19 On details and reports of human sacrifice, cf. B. 
Boal 1999: 275-326; F. Padel 1995

20 The motif of a ritual pot being thrown down a hill by the deity is known from several places in Orissa where a mountain and a temple in the plains for one and the same deity exist side by side; see, e.g., the temple of Mohuri Kalua, Berhampur; cf. B. Schnepel 1997: 210.

21 Cf. G.D.Sontheimer 1994: 127: "By kshetra I mean inhabited, well-settled space with regular plough agriculture...by vana I mean 'wild space', 'forest' or 'jungle'.. the 'hermitage', the 'tribals",

22 For references, see G.D. Sontheimer 1994, fn. 54.

23 There are many variations of this story; cf. B. Boal 1982: 52; E. Thurston 1909: 368ff., Vol.3; C. Mallebrein 1993: 479.

24 Another name for Kandhenbudhi is Dharni, which is more frequent in the hilly regions; cf. R. Nayak, Boal, Soreng 1990: 64-5. Besides Kandhenbudhi they worship and celebrate various other deities in each village, e.g. in Hilimal, the place of Sulia's mother, among general Hindu deities they worship Puraten Budha, Bastaren, Kalisundari and Mauli.

25 This animal had the shape of a cow. This is why the Khandgia Kondh do not eat cow meat. Similar the Mutkia Kondh do not use the iron vegetablechopper (paniki), the symbol of their clan deity, Patkhanda. It seems that these function like totems; cf. Parkin 1992: 73: "Totemic designations serve as emblems distinguishing individual clans or bonso from one another [and] signal the association of each descent group with the object represented by the totemic name...mostly naturally occurring objects, usually animate".

26 The Sikerpat jatra takes place near Guna on the second day of the bright lunar fortnight of the pausa month (pausa sukla dvitiya). Sikerpat's mother stays at Guna. During this jatra people question the deheri, who belongs to the Daka Kondh, while he is in a trance about all sorts of things, but mainly health and agricultural problems. Other festivals for Sikerpat take place on the second day of the month of asadha dvitiya (June-July), after the ritual transplantation of the rice, and on asadha purnima, when they ask Sikerpat about the quality of the rain and the quantity of crops expected.

27 Sikerpat's wife is Pahagiren, his father's name is Pudapat, and his sister is called Sarkarsani. She is worshipped in the Sonpur region and her festival is Chudakhai Dangar. Some people say that Pahagiren is a daughter of Indra, therefore Sikerpat can forecast rain.

28 The local people speak of around 100-150 goats and four buffalo, brought by outsiders. The Khandgia Kondh do not offer a buffalo.

29 Kuar is a title given to the family. They belong to the Maunsia Kondh.

30 The Kuar family in Hilimal keeps a small family shrine near the kitchen, which women are not allowed to enter. There an axe (tangi), an iron chain (sikla) and a small pot full of water are kept. This is also the place where the ancestors (pidha) stay. They are worshipped twice a year, the day before the Kandhenbudhi festival and on Nuakhia.

31 Formerly the Kuar Umra was responsible for three villages and was in charge of collecting taxes. $\mathrm{He}$ worked under the Zamindar-Raja of Jarasingha.

32 According to one informant Sulia finally accepted a priest from Mahasinghi only. The Maunsia first appointed a Pradhan and then a Majhi Kondh, but both were killed by Sulia in form of a tiger.

33 Every three years, on the last day of the Sulia Puja, Sulia's main axe visits the house of his mother at Hilimal. On that day the villagers perform a puja to him and offer him a goat and a cock.

34 The history of Patkhanda, her festivals and local importance is discussed in C. Mallebrein (2001: 60-83 and Mallebrein 2003a). Some information is given by A. Das 1967-8: 3-30; U.N. Pattnaik 1969-70: 81-4.

35 One can find shrines or temples of Patkhanda at all these places. Her place of origin in Mahasinghi is marked by an unhewn stone in a jungle grove. Her main place of worship in Mahasingi is an open shrine with a decorated stone under a tree. In Baliguda a large new temple, financed mainly by business people, was constructed in 1990 at the site of the former open shrine under a tree. Another important centre of Patkhanda worship is at Buanpada (Bolangir district), where a yearly jatra, similar to that at Jarasingha, is performed.

36 The hill gods play an important role in this area. They guard and protect the area and its people and are responsible for the health and well-being of the community. It is believed that the hill gods punish those who pollute their area by spitting, urinating or cutting the tree or its branches by giving them fever. All the gods in this area have their specific responsibility: for personal problems, people apply to Sulia, while the goddess Kandhen Budhi takes care of the fertility of the village and the people.

37 On the role of the tribal deities as istadevata at the princely courts of Orissa, see Kulke 1992.

38 This development is discussed by Kulke 1993.

39 The priest of Patkhanda in Jarasingha, Rajkumar Thanapati, belongs to the Dholo Kondh chak.

40 Traditionally the festivals for tribal deities take place in the month of pausa; cf. Sulia and Sikerpat. The Rajas started to celebrate the Dashahara festival with great pomp in the new centres of royal power. At the centre of the festival was the Raja and his tutelary deity, who granted him the right to rule. According to Schnepel (1997), the king was the main actor in the spectacle, the patron of the ritual events, the centre of the kingdom and even the cosmos. For further information on the Dashahara festival in Jeypore, Orissa, see Schnepel 1997: 22962; on Jagdalpur (Bastar), see Mallebrein 1996. For important literature on Dashahara festivals in other parts of India, see Schnepel, fn.16; Wilke 1996, Sontheimer 1981, Kane 1958.

41 The author suggests that the three finger-like metal parts recall the three parts of the iron paniki that was once stolen by a Brahman.

42 Sulia is worshipped three times a year, in the month of pausa, bright half (sukla pakhya) on the first Tuesday; and in the month of shravan (sukla pakhya). On the first Tuesday they offer milk to the tiger (Sulia), then in the month of bhadra (sukla pakhya) on the first Tuesday they throw 
sand (bali) on Sulia pada, the ritual field. In this region they also worship another Sulia God, San Sulia. His festival is performed in the village of Purunapani and takes place one week after the Sulia festival.

43 Sulia only possesses a Kuar Maunsia deheri, not a deheri from another clan.

44 Besides healing during festivals the deheri also heal when they are asked by devotees for help. Then they do not enter a state of trance. They detect disease-causing spirits by rubbing rice grains in a winnowing fan. If this does not bring an reliable result, they are possessed by a deity, who tells the cause of the disease.

45 Among the important hill gods of this area are Tel Palen, Bhuasen, Bhim Budha, Makri Budhi, Bomkhai Budha, Gaekhai Budha and Mathakhai Budha.

46 All major villages in this region take part at the Sulia festival, such as Khairaguda, Hilimal (associated with Sulia's mother in which village Biranchi Kuar, the main Kuar, stays), Telapali, Jamjharan, Purunapani, Kumria and Mukundpur. The deheri come from theses villages.

47 People who suffer from mental problems or are said to be possessed by dangerous spirits are beaten with the iron chain by the deheri.

48 All the other deheri meet at around 8 am at the ritual site. Each one brings Sulia's axe from the village and household shrine.

49 The modern cement enclosure of the ritual site also includes a small roofless enclosure, which serves as a resting place for the deheri and a store room for the ritual paraphernalia.

50 According to one informant, during the Sulia puja 110 deities take part, besides Sulia Budha. Among them are Khapsa Budha, Pahagiren, Kalisundari, Bastaren, Mauli Devata, Pijudungri, Makri Budha, Bad Dungari and Sikerpat. Patkhanda from Jarasingha does not take part, as she is a Rajadevata; only jungle and hill deities participate and enjoy the offerings. Not all the 110 gods possess the deheri; the priest just recites their names and offers them chicken, rice and liquor.

51 Pahagiren takes possession of a Maunsia Kondh.

52 The deity Pathargad is said to come from armul chakda, a swidden field in a mountain between Sonepur and Boudh. His deheri, a Maunsia Kondh, is possessed several times during the festivals, such as Dashahara, Kadua jatra, Makri jatra and Puraten jatra, as well as when he is called to perform a healing ritual. He is not exclusively possessed byPathargad: other deities can also enter his body, like Khagsa from Mahasinghi, Pahagiren and Kandhenbudhi. In this case it is the deity himself who speaks through his mouth and informs the priest of his arrival.

53 The first animal sacrifice is provided by the Kuar family of Hilimal; the castrated male goat is called pat-buka and has to be killed by a single stroke. Only then do the other participants offer their animals. Only members who belong to the Kuar Kondh are allowed to kill he-goats and buffalos.

54 According to one participant, most of the devotes, around $80-90 \%$, offer an animal because their wish has been fulfilled by Sulia, the largest offering being a buffalo. The devotees do not object to animal sacrifice, as this is proof of Sulia's power

55 On this topic, see C. Mallebrein, 2003b, in press.

56 According to some devotees the name of his wife is Bhuasuni.

57 Sulia is male and is called Budha, "old fellow"; he is not linked with any goddess or wife. The village Khairaguda is also called svarga pitha. Sulia is called Shiva in the same way that prominent tribal goddesses are considered forms of Durga.

58 As many participants in the festival at Jarasingha do object to the priest drinking the blood of the animal in public, his assistants cover his head with a cloth.

\section{REFERENCES}

Behera, B. K. 1996. Tribal Culture, Modernisation and Development. A Study of Kondh Tribes. New Delhi: Khama Publishers.

Berkemer, G. 1993. Little Kingdoms in Kalinga. Ideologie, Legitimation und Politik Regionaler Eliten. Stuttgart: Franz Steiner Verlag.

Boal, B. 1982. The Konds. Human Sacrifice and Religious Change. Warminster: Aris \& Phillips.

__ 1999. Man, The Gods and the Search for Cosmic Wellbeing, Bhubaneswar: NISWASS National Institute of Social Work and Social Sciences.

Dalton, E. T. 1872. Descriptive Ethnology of Bengal. Illustrated by Lithograph Portraits copied from Photographs. Calcutta: Office of the Superintendent of Government (reprint under the title: Tribal History of Eastern India. New Delhi: Cosmos 1978).

Das, A. 1967-8. "Study of the Socio-religious Life of of Tribals in Guduvella area, Bolangir District," Adibasi 4 (9): 3-30.

Eschmann, A. 1978. "Hinduization of Tribal Deities in Orissa: The Shakta and Shaiva Typology" (pp. 7997), in A. Eschmann, H. Kulke and G.C. Tripathi (eds.), The Cult of Jagannath and the Regional Tradition of Orissa. New Delhi: Manohar Publishers.

Hacker, K. F. 1999. "Displaying a Tribal Imaginary: Known and Unknown India," Museum Anthropology, 23 (3): 5-25.

Kane, P.V.1958. "Durgotsava" (pp. 154-85), in History of Dharmashastra (Ancient and Mediaeval Religious and Civial Law in India), 5 (1). Poona: Bhandarkar Oriental Research Institute.

Kulke, H. 1992. "Tribal Deities at Princely Courts: The Feudatory Rajas of Central Orissa and their Tutelary Deities" (pp. 56-78), in S. Mahapatra (ed.), The Realm of the Sacred. Verbal Symbolism and Ritual Structures. Calcutta: Oxford University Press.

_- 1993. "Legitimation and Townplanning in the Feudatory States of Central Orissa" (pp. 93-113), in H. Kulke (ed.), Kings and Cults. Delhi: Manohar.

Mallebrein, C. 1993. Die anderen Götter. Volks- und Stammesbronzen aus Indien. Heidelberg: Edition Braus.

1996. "Danteshvari, the Family Goddess (kulsvamini) of the Rajas of Bastar, and the 
Dashahara-Festival of Jagdalpur" (pp. 483-511), in A. Michaels, C. Vogelsanger and A. Wilke (eds.), Wild Goddesses in India and Nepal. Berne: Peter Lang.

Mallebrein, C. 2001. "Entering the Realm of Durga: Patkhanda, a Hinduized Tribal Deity", in The Fourth World. Journal of the Marginalized People. NISWASS: $60-83$.

_. 2003a. "Entering the Realm of Durga: Patkhanda, a Hinduized Tribal Deity", in A.Malinar, H. Frese and J. Beltz (eds.), Text and Context in Orissa (and beyond). Heidelberg, Delhi: Manohar 2003 (in print).

_.. 2003b. "When the Buffalo becomes a Pumpkin: The Animal Sacrifice Contested", in G. Pfeffer (ed.), Centre and Periphery: Groups, Categories, Values. Delhi, Heidelberg (forthcoming).

Nayak, R., B. Boal and N. Soreng. 1990. The Kondhs A Handbook for Development. New Delhi: Indian Social Institute.

Padel, Felix. 1995. The Sacrifice of Human Being. British
Rule and the Konds of Orissa. Delhi: Oxford University Press

Parkin, Robert. 1992. The Munda of Central India. An Account of their Social Organization. Delhi: Oxford University Press.

Pattnaik, U.N. 1969-70. "Religious Ceremonies, Ordeals and a Legend about Oriya Infiltration in Kondh Hills," in Adibasi 4 (9): 81-4.

Schnepel, B. 1997. Die Dschungelkönige. Ethnohistorische Aspekte von Politik und Ritual in Südorissal Indien. Stuttgart: Franz Steiner Verlag.

Sontheimer, G. 1994. "The Vana and the Ksetra: The Tribal Background of Some Famous Cults" (pp. 11764), in G.C. Tripathi and Hermann Kulke, eds., Eschmann Memorial Lectures. New Delhi: Manohar. Thurston, E. 1909. Castes and Tribes of Southern India. 7 Vols. Madras (reprint: Delhi 1975).

Wilke, A. 1996. "Mythos in Bewegung. Die Grosse Göttin in Symbolsystem, Kultus und Alltag", in Zeitschrift für Missionswissenschaft und Religionswissenschaft 80 (4): 265-83.

Author's Address: Cornelia Mallebrein, Seminar for Indology and Comparative Science of Religion, Department of Indology, Münzgasse 30, 72070 Tübingen, GERMANY E-mail: mallebrein@aol.com 